\title{
The dog that barks doesn't bite: coverage and compliance of sectoral minimum wages in Italy
}

\author{
Andrea Garnero 1,2,3
}

\author{
Correspondence: andrea.garnero@ \\ oecd.org \\ ${ }^{1}$ OECD, 2, rue André Pascal -, 75775 \\ Paris Cedex 16, France \\ ${ }^{2}$ CEB, Université libre de Bruxelles, \\ Brussels, Belgium \\ Full list of author information is \\ available at the end of the article
}

\begin{abstract}
This paper provides a comprehensive portrait of the level and compliance with sectoral minimum wages in Italy between 2008 and 2015. The results show that wage floors in Italy are relatively high both in absolute terms and relative to the median wage. However, non-compliance rates are not negligible: on average, around $10 \%$ of workers are paid $20 \%$ less than the minimum wage established in their reference collective agreement. Non-compliance is particularly high in the South and in micro and small firms, and it affects especially women and temporary workers. Overall, wages in the bottom of the distribution appear to be largely unaffected by minimum wage increases. More effective enforcement practices are therefore needed to safeguard a level playing field for firms and ensure that minimum wage increases are effectively reflected in pay increases for workers at the bottom of the distribution.
\end{abstract}

JEL Classification: J08, J31, J52, J83

Keywords: Minimum wages, Collective bargaining, Compliance

\section{Introduction}

Minimum wages are back at the centre of the debate in many countries in the world. In some countries, the debates have focused around the introduction of a national minimum wage. For instance, Germany, which did not have a national minimum wage, introduced one in 2015. Italy and South Africa are also discussing the opportunity to introduce a minimum wage at a national level. In other countries where statutory minimum wages already exist, the debates after the crisis have turned around their level. For instance, the Conservative Government in the UK decided to increase the minimum wage for adults to $60 \%$ of the median wage by 2020 (currently it is around $50 \%$ ). In the USA, the fight for a $15 \$$ minimum wage gained some ground and some cities have passed legislation to bring this to effect. In Europe, over many years, unions and associations have discussed the possibility of introducing minimum wages at the local level to better take into account the costs of living (e.g. London living wage) or harmonise European wage policies through a EU-level minimum wage.

The research on the topic has mainly focused on the impact of minimum wages on employment (see, among many others, the seminal papers by Neumark and Wascher, 1992 and Card and Krueger, 1994) or on poverty (e.g. Sabia and Burkhauser, 2010 and MaCurdy, 2015), while more recently it also studied the effect on prices (Allegretto and Reich, 2015), profits (Draca et al. 2011) and productivity (Riley and Rosazza-

(c) The Author(s). 2018 Open Access This article is distributed under the terms of the Creative Commons Attribution 4.0 International License (http://creativecommons.org/licenses/by/4.0/), which permits unrestricted use, distribution, and reproduction in any medium, provided you give appropriate credit to the original author(s) and the source, provide a link to the Creative Commons license, and indicate if changes were made. 
Bondibene, 2015). Strikingly, the aspect of compliance of the established minimum wage rates has been largely overlooked in OECD countries. Ashenfelter and Smith (1979) first investigated the patterns of minimum wage compliance in the USA noting that "in the midst of numerous studies intended to establish the quantitative effects of the minimum wage law, it is remarkable that no one has bothered to establish that this law actually affects wage rates [...] presumably reflecting the belief that employers fully comply with this law". Ashenfelter and Smith (1979) found that compliance in the USA in the 1970s was substantial but not complete and concluded that "the most useful future analyses of the effects [of the minimum wage] will incorporate a thorough analysis of the compliance issue." More than three decades after this seminal paper, compliance to the minimum wage as well as, more in general, the issue of the enforcement of labour regulations is still rarely analysed (Ronconi, 2010). Only few, and often tentative, estimates of non-compliance to minimum wage regulations are available and mainly for emerging economies. Moreover, existing analyses focus on minimum wages set at a national level and disregard wage floors set by collective agreements which in several European countries are the most important wage setting institution.

This paper extends the analysis of non-compliance to sectoral minimum wages set by collective agreements in the case of Italy. In Italy, as in many other European countries, trade unions and employers' organisations negotiate sectoral wage floors but little is known about their level, coverage and compliance. The contribution of this paper is therefore twofold: first, it provides a comprehensive and detailed portrait of sectoral wage floors in Italy by year, region, firm and workforce characteristics. Second, it estimates the degree of non-compliance with the sectoral minimum wages using three alternative data sources on wages matched to a dataset on negotiated wages and looking not only at the share of underpaid workers but also at the size of underpayment by year, region, firm and workers' characteristics.

The results show that sectoral wage floors in Italy are relatively high both in absolute terms and relative to the median wage. However, on average, around $10 \%$ of workers are paid $20 \%$ less than the minimum wage as established in the collective agreement of reference. Non-compliance is particularly high in the South and in micro and small firms, and it affects especially women and temporary workers. Moreover, wages at the bottom of the distribution appear to be largely unaffected by increases in sectoral wage floors.

The remainder of this paper is organised as follows. Section 2 summarises the existing literature while Section 3 presents the institutional setting and provides a detailed statistical portrait of sectoral wage floors in Italy between 2008 and 2015. Section 4 presents and discusses the estimates of the number of workers paid less than the sectoral minimum wages and some robustness tests using alternative data sources. Section 5 concludes by discussing the results and the policy implications for Italy.

\section{Literature review}

Enforcement of and compliance with minimum wages are crucial dimensions for their effective functioning. In some countries, especially where authorities seem to turn a blind eye, ${ }^{1}$ not complying with the minimum wage rate is the most straightforward channel of adjustment to minimum wage increases instead of firing workers or increasing productivity. Firms can use many channels to pay lower minimum wages (and hence lower taxes and social contributions). First, they may reduce the number of formal 
employees and increase the number of informal ones. Standard theoretical models show that in a dual labour market an increase in wages in the formal sector induces a displacement of workers towards the informal sector where lower wages can be paid. Empirical evidence for several developing and emerging economies shows that increases in the minimum wage are reflected in an increase in informal employment (see among many Comola and De Mello, 2011 for Indonesia or Gindling and Terrell, 2005 for Costa Rica). Second, in some countries, firms may reduce the number of standard dependent employees and increase the number of non-standard ones who are not or poorly covered by the minimum wage legislation (either at a national or sectoral level). This may include for instance, bogus self-employed, casual workers or project workers who are hired in theory for a particular project or task with no predefined working time but often used as disguised dependent employees (see for instance some evidence for Poland in Kamińska and Lewandowski, 2015). Third, firms may hire regular and fully formal employees paid at the minimum wage but ask them to work unpaid extra hours. In this case, firms would comply with the monthly or annual rate of the minimum wage but would not comply with the hourly rate. Fourth, since collective agreements define not only the base wage but also wages by occupation and level (skills and/or seniority), firms may assign workers to a lower level than the correct one in order to underpay them. Fifth, in complex wage setting institutions (e.g. where more than one minimum wage rate applies), employers, especially in micro and small firms where no professional HR or union exist, may refer to the wrong agreement and "inadvertently" pay less than the reference minimum wage or apply the most convenient collective agreement when the sectoral classification is not clear or when several agreements are potentially applicable. Rani et al. (2013) did indeed find that in developing countries the rate of compliance is negatively related to the number of minimum wages. Finally, in those systems where wage floors are set at a sectoral level by social partners and where there are no (or limited) rules to establish the representativeness of social partners which can sign legally binding agreements, employers can even set their own wage floors below the existing ones signing a "pirate" agreement with a complacent poorly representative union or a "yellow" union (a workers' organisation set up or influenced by an employer). ${ }^{2}$ Moreover, non-compliance is likely to be more acute where wage floors are more binding. Therefore, poorer regions, micro and small firms, low-skilled and temporary workers are at particular risk.

Most existing papers measuring non-compliance to minimum wages (either statutory or occupation/sectoral minimum wages) focus on developing countries. Rani et al. (2013) estimated non-compliance in 11 developing countries and they found that noncompliance ranged from $5 \%$ in Vietnam to $51 \%$ in Indonesia in the late 2000 s. Kanbur et al. (2013) provided evidence for Chile over many years: the number of workers paid less than the minimum wage steadily increased from $15 \%$ in 1990 to $29 \%$ in 2006 and then fell back to $15 \%$ in 2009. In the case of South Africa, Bhorat et al. (2012) estimated an average violation of sectoral minimum wages of $44 \%$ in 2007 ranging from $9 \%$ among civil engineers to 67\% among security workers. Bhorat et al. (2015) provided evidence for seven sub-Saharan African countries and they found an average noncompliance of $58 \%$, from $20 \%$ in Tanzania to $80 \%$ in Mali. Ye et al. (2015) found that compliance in China is quite high (only $3.5 \%$ of full-time workers earn less than the legal monthly minimum wage), but they found evidence for substantial non-compliance with overtime pay regulations ( $29 \%$ of the employees who work overtime are not paid 
any additional wage, and $70 \%$ are paid less than the legally required 1.5 times the regular wage).

The evidence for developed countries is more limited. The US Bureau of Labor Statistics provides an official estimate of the share of workers paid less than the minimum but the sample is restricted to workers paid at hourly rates $58.5 \%$ of all wage and salary workers). In 2015, the share of workers paid less than the minimum in the USA was $2.2 \%$, down from the peak of $13.4 \%$ recorded in 1979 , when these data were first published on a regular basis. The UK Low Pay Commission provides estimates for non-compliance in its annual reports. Since the introduction of the national minimum wage, non-compliance has always been quite low, around 1\% among all workers, but much higher for workers under 20 years old (from around 3.5\% in 1999 to 8\% in 2015). ${ }^{3}$ The German Mindestlohn Kommission in its first report on the new German minimum wage calculates that in 2015 2.7\% of German workers were paid less than the minimum. In Japan, the Ministry of Labour found that in 2014, among inspected companies, $10.7 \%$ did not comply with the minimum wage regulation. Garnero et al. (2015) provide cross-country evidence for 17 EU countries between 2007 and 2009 and find an average non-compliance rate of about $3.5 \%$ but with considerable variations across countries: from $13 \%$ in Italy to less than $2 \%$ in Denmark among countries without a statutory minimum wage or from $7 \%$ in France to less than 1\% in Bulgaria. Goraus and Lewandowski (2016) focus on ten Central and Eastern European countries and find that on average in 2003-2012, the share of workers paid less than the minimum wage ranged from $1.0 \%$ in Bulgaria to $4.7 \%$ in Poland and Hungary, $5.6 \%$ in Latvia and 6.9\% in Lithuania. Finally, Lucifora (2017) has also estimated the degree of non-compliance in Italy using 30 collective agreements: he finds a rate of noncompliance of around 21\% in 2009 and 2015 based on the LFS and about 9 and 11\% using SES and INPS data. The analysis in the next sections is based on a more representative set of agreements (90 sector-level agreements) and includes also agreements signed with smaller employers' associations which may pay lower wages. The smaller set of agreements used by Lucifora (2017) is the main factor explaining higher non-compliance estimates than those found in this paper.

\section{How are wages set in Italy?}

In Italy, there is no national or subnational statutory minimum wage but wage floors are fixed by collective agreements between trade unions and employer organisations at the sectoral and a firm or sometimes local level. Sector-level bargaining is devoted to maintaining wages' purchasing power, while firm-level bargaining aims at redistributing productivity gains.

This system goes back to the early twentieth century when the first company or territorial level collective agreements were introduced in manufacturing and agriculture while the first nationwide sectoral agreement was signed immediately after World War I (Giugni, 1957). Currently, more than 800 sectoral collective agreements cover practically all private-sector employees in Italy (96\% according to data from the European Company Survey, 99\% using data from the Structure of Earnings Survey) while trade union density (the number of members over the total number of employees) is below $40 \%$ in the private sector and employers' organisation density just above $50 \%$. Currently, valid agreements range from the 
traditional ones such as those covering metal or chemical workers to more "exotic" ones such as collective agreements for emotional coaches and sacristans.

Formally, a collective agreement in Italy applies only to workers of the signatory parties, i.e. to workers who are members of the signatory union(s) and firms that are members of the signatory employers' organisation(s). No formal extension mechanisms of the terms set in collective agreements to workers in firms not members of an employers' organisation are present in Italy while they are quite common in other European countries (almost automatic extensions are granted in Austria, Belgium, Finland or France while in Germany extensions are granted under specific conditions, see OECD, 2017 for more details). However, in Italy, base wages fixed in sector-level agreements (minimi tabellari) are used by labour courts as a reference to determine if the firm complies with Article 36 of the Italian Constitution which states that "workers have the right to a remuneration commensurate to the quantity and quality of their work and in any case such as to ensure them and their families a free and dignified existence". Base wages in sector-level agreements are therefore used in the Italian jurisprudence as functional equivalents of sectoral minimum wages for all workers to which all firms have to comply.

Collective agreements are therefore the most relevant wage setting institution in Italy but surprisingly very little is known about the level and the "bite" of negotiated wages, neither on average, nor across sectors, regions, firms' and workers' characteristics. Currently, no comprehensive descriptive evidence on existing collective agreements in Italy is available. ISTAT publishes just a monthly index of the evolution of negotiated wages but not their level or "bite" (i.e. the number of people covered or the level of the minimum wage compared to the median/average wage) across geographical areas or firms' types. Since negotiated wages are the same for the entire country, well-known regional variations in terms of economic development and cost of living (GDP per capita is around $43 \%$ lower in the south than in the north of Italy) are not taken into account during the negotiations nor are the (often massive) differences between firms in the same sector (and there is limited possibility to opt-out from the collective agreement). ${ }^{4}$ Moreover, given the size of the black (informal) economy and the development of non-regular forms of work who are either not or poorly covered by collective agreements, some researchers and trade unionists are increasingly concerned that the actual coverage of negotiated wages is well below the almost $100 \%$ figure provided by surveys such as the Structure of Earnings Survey or the European Company Survey.

It is therefore not surprising that the Italian collective bargaining system has come under pressure in recent years (even before the crisis) since some economists, labour lawyers and politicians see it as the source of excessive wage rigidities that limit flexibility in time of difficulties, hinder regional reallocation and contributes to the stagnation Italy has experienced over the last 20 years. The largest employers' association, Confindustria, has called for higher decentralisation in wage setting, giving greater importance to firm-level bargaining. The biggest company in Italy, FIAT, even exited Confindustria in 2009 (and it is still not a member) in order to freely bargain a different establishment-level agreement (though the resulting controversy was about work organisation rather than wages). Unions and employers' organisations have generally only agreed to minor tweaks to the current system (for instance, by additionally promoting firm-level bargaining through fiscal incentives or strengthening social partners' representativeness). 


\subsection{A statistical portrait of sectoral minimum wages in Italy}

In our analysis, we will focus on a sample of the most representative agreements (in terms of workers covered) that ISTAT collects for its database on collective agreements and contractual wages. ISTAT collects data on negotiated gross wages, therefore including tax and social security contributions paid by employees, in around 90 collective agreements (the most representative ones), and the data used in this analysis represent a specific extraction of the minimum value in each agreement (therefore the lowest occupational level excluding seniority or other pay elements defined in collective agreements such as wage supplements for night shifts or particular activities, or bonuses). ${ }^{5}$ These wage data represent wages before taxes and transfers and in many cases they also account for the presence in the agreement of a 13th and a 14th month which are not bonuses but are part of the base wage paid in December and/or June each year. Moreover, they also account for the presence of arrears in the case of late renewal (salari di competenza). Bonuses related to individual performance or individual working conditions, supplementary payment agreed at the company or local level are not included. The ISTAT minimum wage data are classified by NACE rev. 2 at two-digit codes using a mapping established by ISTAT (and by Nace rev. 1 before 2011).

In order to compute the Kaitz index, i.e. the level of the minimum wage compared to the median wage, the sectoral minimum wage data are then matched by NACE twodigit codes to individual wage data from the Italian Labour Force Survey (LFS) between 2008 and 2015. The LFS collects net wage data, and therefore in order to make individual wage data comparable with ISTAT minimum wage data, LFS net wages are converted to gross wages using income tax rate and social security contributions (as a $\%$ of net wages) for different levels of the average wage (from 1 to 200\%) in the case of a single person without children from the OECD TaxBen model. We assume that this is the effective tax rate for all workers each month before tax adjustments and transfers done at the end of the year to take into account family composition and household total income. Individual wage data are further inflated to add the 13th and 14th months in sectors that also have to include a 13th (all sectors) and a 14th month (around 40\% of the agreements in the sample). Finally, only employees are considered (apprentices and domestic workers are excluded but also co.co.pro, casual work, and the like because of missing wage data in the LFS). Since LFS data may suffer from measurement error (more on this in the next section on the estimation of non-compliance), we also match the wage floors data to an employers' survey and the Structure of Earnings Survey and to administrative data from the Italian National Social Security Institute (Istituto Nazionale della Previdenza Sociale-henceforth INPS). The pros and cons of these datasets and their specific features are discussed in the next section.

In 2015, gross minimum wages in collective agreements were on average 9.41 euros/h including the 13th and the 14th month (if paid), 17.7\% higher than in 2008 when they were around 8 euros/h. Minimum wages ranged from 7.47 to 13.89 euros/h. (Table 1 ).

Gross minimum wages in collective agreements are very high compared to the median wage as indicated by the so-called Kaitz index (the ratio of the minimum to the median wage). They range between 74 and $80 \%$ using LFS wage data. As a reference, the minimum wage in France was 9.61 euros per hour in 2015, around 60\% of the median, the highest Kaitz in the European Union (among OECD countries, the Kaitz index is $68 \%$ only in Turkey and Chile where the importance of the informal economy 
Table 1 Hourly sectoral minimum wages (nominal euros per hour and Kaitz index), 2008-2015

\begin{tabular}{llllll}
\hline Year & $\begin{array}{l}\text { Hourly minimum wages } \\
\text { (average across sectors) }\end{array}$ & $\begin{array}{l}\text { Kaitz } \\
\text { (\% of the median) }\end{array}$ & $\begin{array}{l}\text { Minimum of } \\
\text { the minima }\end{array}$ & $\begin{array}{l}\text { Maximum of } \\
\text { the minima }\end{array}$ & $\begin{array}{l}\text { Median } \\
\text { LFS }\end{array}$ \\
\hline 2008 & 7.99 & 74.62 & 6.55 & 12.27 & 10.71 \\
2009 & 8.22 & 74.88 & 6.65 & 12.43 & 10.97 \\
2010 & 8.46 & 75.13 & 6.73 & 12.43 & 11.26 \\
2011 & 8.91 & 78.35 & 6.89 & 12.49 & 11.37 \\
2012 & 9.06 & 76.07 & 6.91 & 12.76 & 11.91 \\
2013 & 9.22 & 76.20 & 7.12 & 13.04 & 12.10 \\
2014 & 9.32 & 80.53 & 7.29 & 13.41 & 11.57 \\
2015 & 9.41 & 79.95 & 7.47 & 13.89 & 11.77 \\
\hline
\end{tabular}

Note: The Kaitz is computed as the average of the sectoral minimum wages over the national median. Source: Author's calculation on ISTAT negotiated wages database and the Labour Force Survey

is also very high). High Kaitz indices reflect both high minimum wages negotiated in collective agreements as well as relatively compressed wage scales in Italy (the P90/P10 ratio of wages for full-time equivalent in 2014 was "just" 2.17 compared with an OECD average of 3.46 and P50/P10 is 1.50 compared 1.70 across OECD countries). The estimated Kaitz indices in Table 11 in Appendix 1 using the Structure of Earnings Survey (SES) and social security data from INPS are 10-15\% lower ${ }^{6}$ but still well above $60 \%$ of the median (Table 2).

When looking at sectoral minimum wages by broad sectors (NACE one-digit), wage floors are not surprisingly the lowest in agriculture and the highest in finance. The relative high value for the education sector reflects the fact that in-class working hours are limited and "non in-class" working hours as for instance meetings with parents, meeting with the director and homework, are not accounted for in the collective

Table 2 Hourly sectoral minimum wages by sector (euros per hour and Kaitz index, 2015)

\begin{tabular}{|c|c|c|c|c|c|}
\hline & $\begin{array}{l}\text { Hourly } \\
\text { minimum } \\
\text { wages }\end{array}$ & $\begin{array}{l}\text { Kaitz sectoral } \\
\text { (\% of the median } \\
\text { in the sector) }\end{array}$ & $\begin{array}{l}\text { Kaitz national } \\
\text { (\% of the } \\
\text { national median) }\end{array}$ & $\begin{array}{l}\text { Minimum of } \\
\text { the minima }\end{array}$ & $\begin{array}{l}\text { Maximum of } \\
\text { the minima }\end{array}$ \\
\hline A-B Agriculture and mining & 7.70 & 94.29 & 55.44 & 7.53 & 13.89 \\
\hline $\begin{array}{l}\text { C-D-E Manufacturing, electricity } \\
\text { and water supply }\end{array}$ & 9.47 & 79.88 & 73.11 & 7.66 & 11.03 \\
\hline F Construction & 8.55 & 74.32 & 66.03 & 8.30 & 10.28 \\
\hline G Retail trade & 8.43 & 76.44 & 65.11 & 8.43 & 8.43 \\
\hline H Transport & 8.95 & 70.79 & 69.08 & 7.47 & 9.95 \\
\hline I Hotels and restaurants & 8.41 & 89.04 & 64.92 & 8.41 & 8.41 \\
\hline J Information and communication & 9.19 & 68.17 & 70.94 & 7.50 & 10.26 \\
\hline K Finance and insurance & 12.95 & 69.86 & 99.97 & 12.93 & 12.95 \\
\hline $\begin{array}{l}\text { L-N Real estate, professional and } \\
\text { administrative activities }\end{array}$ & 8.82 & 82.33 & 68.12 & 7.47 & 12.29 \\
\hline O Public administration & 9.72 & 68.31 & 75.04 & 9.72 & 9.72 \\
\hline P Education & 11.77 & 67.12 & 90.85 & 11.77 & 11.77 \\
\hline Q Health & 9.29 & 71.60 & 71.69 & 8.25 & 9.65 \\
\hline $\begin{array}{l}\text { R-U Arts, other activities, } \\
\text { household and intl organisations }\end{array}$ & 8.94 & 110.36 & 69.02 & 8.24 & 12.29 \\
\hline
\end{tabular}


agreement. The sectoral Kaitz (sectoral minimum/sectoral median) is very high in agriculture and even beyond 100\% in Arts and other activities. This means that the minimum is very close to (or above) the median, because many people are paid at the minimum wage level and the distribution is very compressed and/or the number of people paid less than the minimum is important.

As for the national average, Kaitz indices by sector using alternative data sources are lower but reproduce the same patterns. Using SES, Kaitz indices range from 46\% in education to $80 \%$ in hotels and restaurants, to $88 \%$ in real estate and professional activities with a (significant) correlation with LFS Kaitz estimation of $72 \%$. INPS data Kaitz indices range from around 60 to $77 \%$ with a (significant) correlation with LFS Kaitz estimation of $67 \%$.

Since wage floors are fixed at a sectoral level for the entire country, they are the same in all areas and regions of the country with minimal differences due to the industrial composition of the region. However, as Fig. 1 shows, their bite compared to the median wage, as measured by the Kaitz index or their value in purchase power parity is very different reflecting the well-known regional differences between North and South in terms of economic development and cost of living.

Finally, the bite of the minimum wage is much stronger in micro and small firms, which constitute the backbone of the Italian economy, than in big firms. Interestingly, nominal hourly wage floors are slightly lower in micro and small firms: somehow unions and employers partly reflect the sector composition in terms of firm size and hence productivity (among many others Bartelsman and Doms 2000 have shown that the distribution of firm productivity and firm size are closely related) in negotiated wages but not enough to balance the lower median (reflecting the likely lower productivity). Hence, the Kaitz index in micro firms is one third higher than in large firms (Table 3).

Overall, the data on sectoral minimum wages show that sectoral wage floors in Italy are quite high compared to the median wage, in particular in the South and in small firms. But given the importance of informality and the complexity of the system, how many workers are effectively covered by these minimum wages and how many are paid less than the negotiated minima?

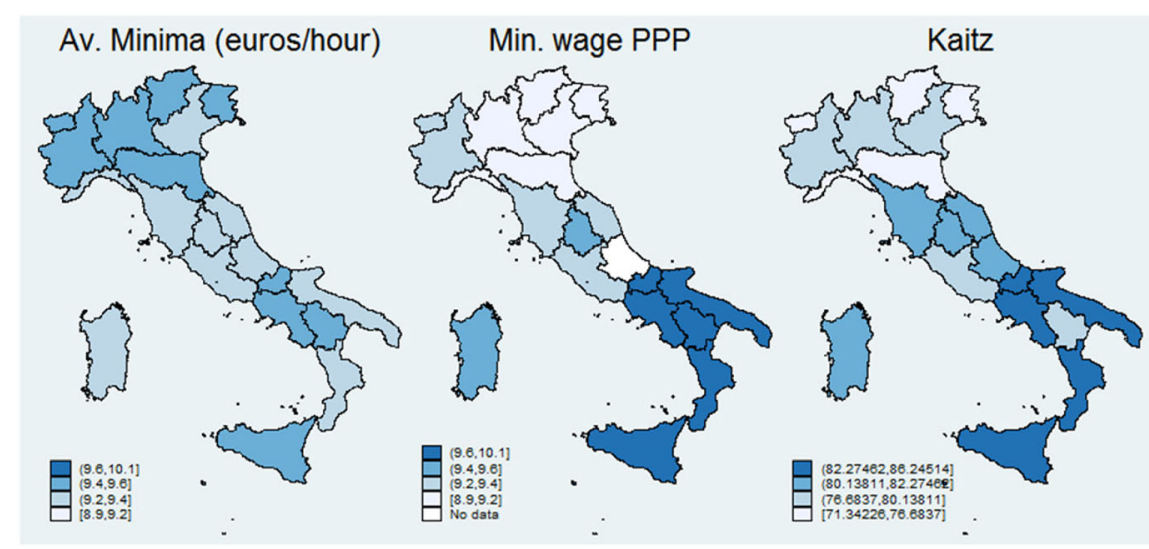

Fig. 1 Nominal minima, minima in PPP and Kaitz index, by region (2015) 
Table 3 Sectoral minimum wages as a percentage of median wage by firm size, 2015

\begin{tabular}{ll}
\hline & Kaitz (\% of the median in the firm size class) \\
\hline Less than 10 employees & 90.93 \\
$11-15$ employees & 79.97 \\
$16-19$ employees & 80.00 \\
$20-49$ employees & 76.17 \\
$50-249$ employees & 72.96 \\
250 or more employees & 68.05 \\
\hline
\end{tabular}

Source: Author's calculation on ISTAT negotiated wages database and LFS

\section{An estimate of non-compliance in Italy}

\subsection{Measuring non-compliance: methodology and data}

Non-compliance with the minimum wage is typically measured as the percentage of workers who are paid below the reference pay rate. However, as Bhorat et al. (2013) highlighted, this is a fairly blunt measure, as it fails to measure the extent of the underpayment. Some workers may be paid only a few cents less than the minimum and even that may just reflect measurement error rather than a real violation. In contrast, other underpaid workers may in fact be paid well below the minimum. Bhorat et al. (2013) proposed using Foster-Greer-Thorbecke (FGT) poverty measures to create a family of violation indices: the simple share of underpaid workers, the depth of the underpayment and the average shortfall per underpaid worker.

Formally, beyond the headcount indicator $v_{0}$ that takes a value of 1 if $w<w_{\min }$ and of 0 when $w \geq w_{\min }$ (where $w$ is the individual wage, $w_{\min }$ is the relevant minimum wage), the measure for the depth of underpayment is defined as:

$v_{1}=\frac{\left(w_{\min }-w\right)^{\alpha}}{w_{\min }}$ if $w<w_{\min }, 0$ otherwise.

where $\alpha$ is a parameter defining the aversion to underpayment. When $\alpha=1, v_{1}$ is the gap between the actual wage and the minimum wage, expressed as a percentage of the minimum wage, with equal weights for all workers. For values of $\alpha$ greater than 1, workers who are more underpaid have higher weight. Finally, an average shortfall per underpaid worker is computed as $v_{1} / v_{0}$.

In this paper, we estimate non-compliance using the sectoral minima provided by ISTAT and individual wages from the Labour Force Survey (LFS). ${ }^{7}$ The Labour Force Survey is the most comprehensive data source for this kind of analysis in terms of sectors covered and because it does not focus only on the formal economy. Being declared by the worker himself (information on wages is available for around $70 \%$ of employees), wages and hours of work in principle are more likely to reflect the actual hourly wages earned by each employee and not those that should have been paid according to the rules. However, data in LFS on wages and hours worked may also be subject to measurement error (though, at least for wages, it would probably reduce the number of workers underpaid since respondents tend to overestimate wages at the bottom of the distribution). ${ }^{8}$ As Ritchie et al. (2016) underline, also sampling and weighting procedures in a survey can be a source of error when estimating non-compliance with the minimum wage.

To account for measurement error in the LFS, we refer to the solutions used in the literature (e.g. Rani et al., 2013, Garnero et al. 2015): first, we allow for a margin of error so that wages "close enough" to the minimum are not considered as non-compliant. In 
particular, when using LFS wages and hours of work, the threshold to compute the family of violation indices is $85 \%$ of the lowest minimum for each NACE two-digit sector. This allows for a margin of error of $15 \%$ (or in the extreme case where individual wages are underestimated and hours of work overestimated, a $-7.5 \%$ margin of error for wages and $+7.5 \%$ margin of error for hours of work). ${ }^{9}$ Second, we confirm the validity of the baseline estimations with LFS using alternative datasets. In particular, we use an employer survey (the Structure of Earnings Survey) and administrative data from social security (INPS).

Wages in the Structure of Earnings Survey are likely to be more precise than those in the LFS. However, being filled-in by the employer, the Structure of Earnings Survey (SES) is also more likely to report only legal workers and wages and hours of work more in line with those fixed by the rules (the law and the reference collective agreement). Moreover, the SES focuses only on firms with more than 10 employees in the business sector, hence excluding agriculture and the public sector and therefore does not cover micro firms and the agriculture sector where non-compliance is likely to be more prevalent. Finally, the SES is available only for 2010.

We further test the robustness of the results using individual (gross) wages in LoSai (LOngitudinal SAmple Inps), a random sample of individuals' social security records from the Italian National Social Security Institute (INPS) for workers working in the private sector during the period 1985 to 2014. This corresponds to around $6 \%$ of the workforce or 1.1 million persons on average per year. ${ }^{10}$ In the case of INPS, data from collective agreements are merged by NACE rev. 1 at two-digit codes. INPS data are by definition the most precise and reliable since they are administrative data used for pensions and social security benefits. However, the flip side is that they report only legal workers paying contributions to the social security system in the private sector. ${ }^{11}$ Moreover, hours of work are not reported and hence the analysis can only be done comparing annual wages, thus focusing only on workers working the entire year fulltime and excluding the potential role of extra unpaid hours of work as a tool not to comply with wages set in collective agreements. Table 4 provides a summary of the features of each dataset. ${ }^{12}$

With respect to the potential channels of underpayment identified in Section 2, the LFS data allow capturing non-compliance due to informality, non-standard forms of work (as long as the worker declares him or herself an employee), unpaid extra hours, "inadvertent" underpayment or the use of "pirate agreements" (agreements legally valid but signed with poorly representative or "yellow" unions). ${ }^{13}$ Given that we do not have detailed data by occupation, skills and seniority and we refer just to the minimum for each NACE two-digit sector, we cannot measure underpayment through lower-thanappropriate job category assignment. With the SES, we are less likely to pick up informal workers or unpaid extra hours. With INPS, only non-compliance due to mistakes, loopholes or pirate agreements is likely to be captured.

Table 5 summarises the family of violation indicators for Italy between 2008 and 2015. More than $10 \%$ of workers are paid less than the wage floor established in their reference collective agreement with a peak of $12 \%$ in 2014. The depth of violation, i.e. the average distance among the entire population from the minimum wage, ranges between 2.30 and 2.60, and as expected, it is positively correlated with the share of underpaid workers. More interestingly, the average shortfall per underpaid worker, i.e. the average distance from the minimum wage for workers paid less than the minimum wage ranges 
Table 4 Comparison of the characteristics of the datasets used to estimate non-compliance in Italy

\begin{tabular}{llll}
\hline & Labour Force Survey & Structure of Earnings Survey & INPS \\
\hline Sectors covered & All & Agriculture and public & administration not included \\
Firm size & All & Private sector & \\
Black economy & Yes & No & All \\
Precision of wage data & Wages declared by & Wages declared by employer & Wages as declared to \\
& employee, subject to error & social security \\
Period of reference for wages & Monthly & Monthly/annual & Annual \\
Workers covered & All & Employees & Employees \\
Hours of work & Yes & Yes & No \\
Channels of underpayment that can be identified using these sources & \\
Informality & Yes & Not likely & No \\
Non-standard forms of work & Partly & No & No \\
Unpaid extra hours & Yes & Not likely & No \\
Lower occupation & No & No & No \\
Mistake or loophole & Yes & Yes & Yes \\
"Pirate" agreements & Yes & Yes & Yes \\
\hline
\end{tabular}

between 20 and 23\%. Between 2008 and 2015, in Italy, around one tenth of the workers are paid less than the reference minima and on average they are paid between one fifth and one quarter less than what is established in collective agreements. The results in terms of the number of workers paid less than the minimum are in line with those previously found by Garnero et al. (2015) for Italy. The results also show that the amount of underpayment per underpaid worker (the average shortfall) is not minor and comparable with estimates for Central and Eastern European countries by Goraus and Lewandowski (2016) who find that the average shortfall goes from around 10\% in Estonia to 40\% in Slovenia.

Focusing only on full-time workers working the entire month, we can disentangle the share of violations linked to an outright underpayment of the monthly minimum wage (workers whose monthly wage is lower than the monthly minimum established in the reference collective agreement) from underpayment via unpaid extra working hours (workers whose monthly wage is in line with the minimum but who are actually paid less once accounting for the actual number of hours worked).

Table 5 Violation of hourly sectoral minimum wages, 2008-2015

\begin{tabular}{llll}
\hline Year & \% of workers underpaid $\left(v_{0}\right)$ & Depth of violation $\left(v_{1}\right)$ & Average shortfall per underpaid worker $\left(v_{1} / v_{0}\right)$ \\
\hline 2008 & 10.35 & 2.28 & 22.04 \\
2009 & 10.48 & 2.30 & 21.98 \\
2010 & 10.87 & 2.50 & 22.99 \\
2011 & 11.77 & 2.63 & 22.37 \\
2012 & 10.25 & 2.29 & 22.33 \\
2013 & 10.88 & 2.45 & 22.52 \\
2014 & 12.39 & 2.51 & 20.24 \\
2015 & 11.99 & 2.47 & 20.64 \\
\hline
\end{tabular}

Source: Author's calculation on ISTAT negotiated wages database and LFS 
In Fig. 2, we see that almost two thirds of the violations represent an underpayment compared with the agreed monthly minimum. Between 6 and 7\% of workers in Italy receive a monthly wage lower than the one agreed in collective agreements. Fighting against this form of violation should be fairly easy because it would be enough to compare the monthly payslip (if existing) to the minimum in the reference agreement. In contrast, around $4 \%$ receive a monthly wage in line with the minimum but are asked to work unpaid extra hours and therefore their hourly minimum is lower than the agreed one. This kind of violation is certainly more complicated for labour inspectors to detect.

Violations occur in all industries (Table 6). Not surprisingly, they are stronger in agriculture and mining, arts and other activities, hotels and restaurants where nonstandard and informal forms of work are more concentrated. In the construction sector, the share of underpaid workers is lower than the average, but the average shortfall per underpaid worker is quite high (almost a quarter of the reference wage floor). Overall, a negative relationship emerges between the share of underpaid workers and the average shortfall per worker. In those industries where there are many underpaid workers, the average shortfall is relatively lower.

Violations of sectoral wage floors are much more prevalent in the South where minima are higher in real terms and compared with the sectoral median: Fig. 3 shows that the share of underpaid workers ranges from around $8.5 \%$ of the workforce in the North-East to $18.5 \%$ in the South. Interestingly, the average shortfall per underpaid worker shows no clear territorial divide. The probability of being underpaid is much higher in the South, but the size of the violation is comparable between the North and the South.

We also look at the share and depth of violations across firm size, and we find a negative linear relationship between firm size and the share of underpaid workers. The number of workers paid less than the minimum wage is very limited in large firms while it is very high in micro firms while the average shortfall is more similar across firms of different size. (Table 7).

Finally, we also compute the probability of being paid less than the minimum wage by workforce characteristics using a logistic regression controlling for firm size, sector

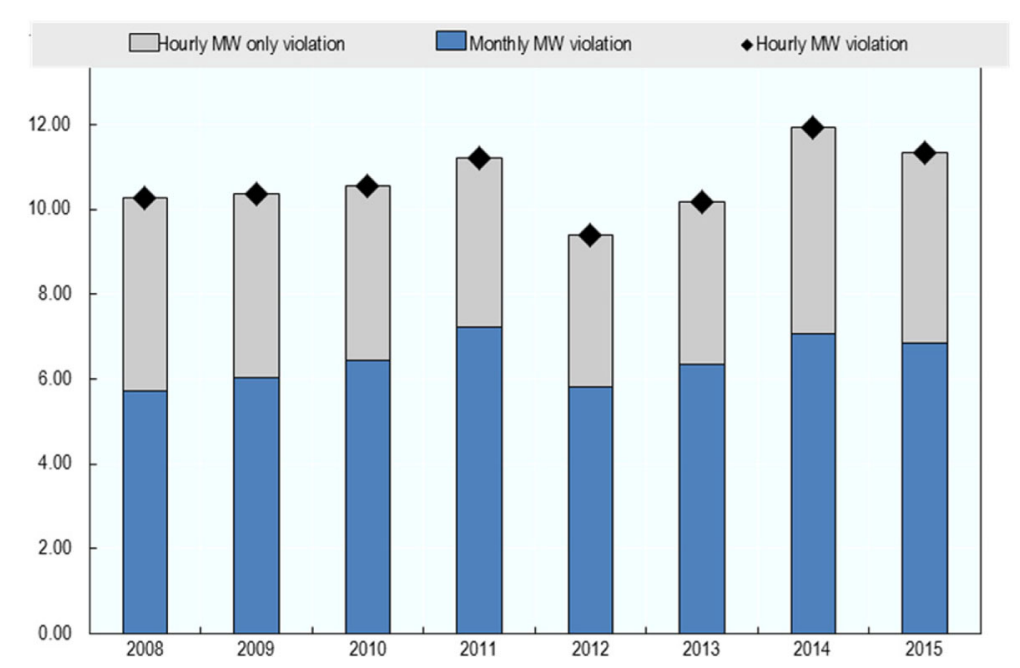

Fig. 2 Monthly vs. hourly only violations, 2008-2015 
Table 6 Violation of hourly sectoral minimum wages, by industry in 2015

\begin{tabular}{llll}
\hline Industry & $\begin{array}{l}\text { \% of workers } \\
\text { underpaid }\end{array}$ & $\begin{array}{l}\text { Depth of } \\
\text { violation }\end{array}$ & $\begin{array}{l}\text { Average shortfall per } \\
\text { underpaid worker }\end{array}$ \\
\hline A-B Agriculture and mining & 31.63 & 7.11 & 22.48 \\
C-D-E Manufacturing, elec. \& water supply & 10.12 & 2.05 & 20.23 \\
F Construction & 7.41 & 1.83 & 24.69 \\
G Retail trade & 11.81 & 2.83 & 23.99 \\
H Transport & 7.93 & 1.68 & 21.22 \\
I Hotels and restaurants & 20.66 & 4.87 & 23.58 \\
J Information and communication & 7.02 & 1.43 & 20.43 \\
K Finance and insurance & 10.24 & 2.42 & 23.65 \\
L-N Real estate, professional \& admin activities & 15.48 & 3.39 & 21.91 \\
O Public administration & 4.15 & 1.29 & 31.24 \\
P Education & 15.07 & 2.56 & 16.97 \\
Q Health & 8.20 & 2.03 & 24.73 \\
R-U Arts, other activities, household and intl organisations & 30.89 & 1.89 & 6.12 \\
\hline
\end{tabular}

Source: Author's calculation on ISTAT negotiated wages database and LFS

of work and region of residence. Conditional on being employed and all else being equal, Fig. 4 shows that women are 2.5 times more likely to be underpaid, while prime age and older workers are $50 \%$ less likely to be paid less than the minimum wage compared with young workers (20-29 years old). Blue-collar workers are more likely to be paid less than the minimum as well as temporary workers (two times more). Interestingly, all else being equal, part-time workers are less likely to be paid less than the hourly minimum (probably it is more difficult to ask part-time workers to do extra hours) while the probability of being paid less than the minimum goes down with tenure.

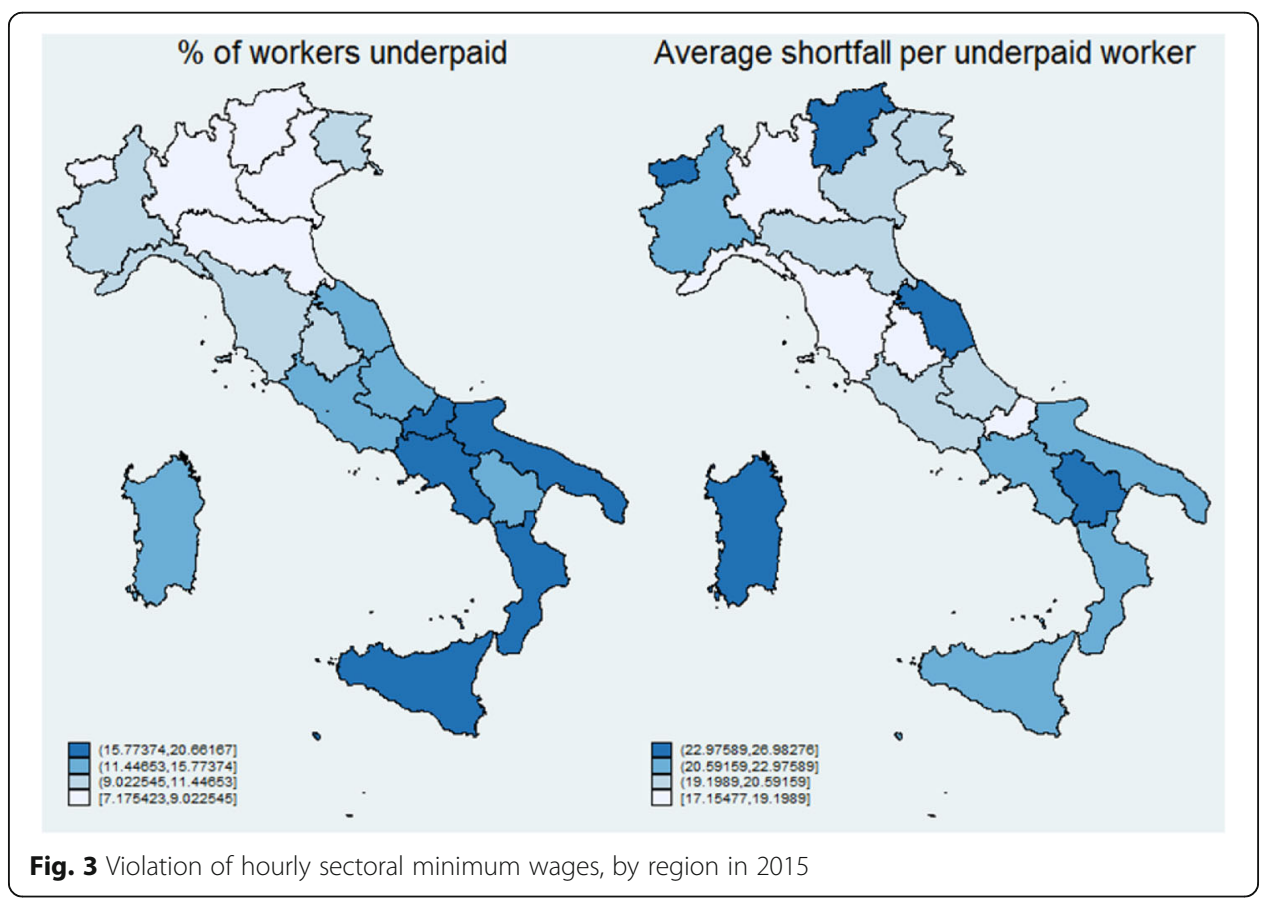


Table 7 Violation of hourly sectoral minimum wages, by firm size in 2015

\begin{tabular}{llll}
\hline Firm size & \% of workers underpaid & Depth of violation & Average shortfall per underpaid worker \\
\hline Less than 10 employees & 18.79 & 3.15 & 16.78 \\
$11-15$ employees & 13.14 & 2.45 & 18.64 \\
$16-19$ employees & 11.48 & 2.35 & 20.47 \\
$20-49$ employees & 9.17 & 1.57 & 17.12 \\
$50-249$ employees & 6.05 & 0.97 & 16.00 \\
250 or more employees & 3.99 & 0.74 & 18.51 \\
\hline
\end{tabular}

Source: Author's calculation on ISTAT negotiated wages database and LFS

\subsection{Higher minima but also higher non-compliance?}

Previous studies (Garnero et al., 2015, Goraus and Lewandowski, 2016, Rani et al. 2013) found a strongly positive correlation between the level of minimum wage and the share of underpaid workers. This means that higher minimum wages, either at a national or sectoral level, also go together with higher violations. Figure 5 shows that a positive relation between a relatively higher sector minimum wage and a higher share of underpaid workers can also be found in Italy, both looking by industry (panel A) and by region (panel B).

These simple correlations may just pick up a spurious relation, especially because the level of the minimum wage is not an exogenous variable. However, since wages are fixed at a national level for each sector every two (or more) years, their level is largely orthogonal to the specific regional and firm size characteristics and economic conditions. Therefore, in Table 8, we test the relationship between the Kaitz index and the share of underpaid workers, the depth of violation and the average shortfall per underpaid worker exploiting the variation over time of the bite of the minimum wage within region-specific firm size groups.

The regression results show a robust and significant correlation between the Kaitz index and both the share of underpaid workers and the depth of violation: when the Kaitz index increases by 1 percentage point, the share of workers paid less than the minimum increases between 0.2 and 0.3 percentage points (i.e. an increase of around $1.5-3 \%)$, and the depth of violation also increases by $0.04-0.06$ percentage points (i.e. an increase of around 1.6-2.5\%) both in hourly and monthly terms. On the contrary,

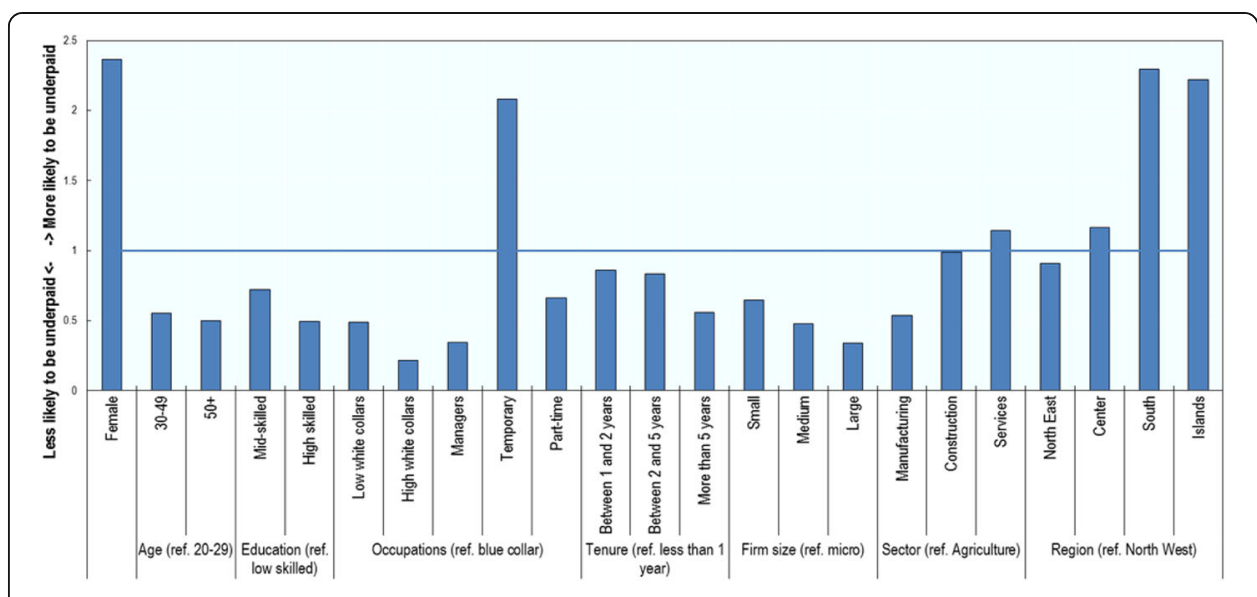

Fig. 4 Probability of being underpaid (odds ratios of a logistic regression, 2008-2015) 


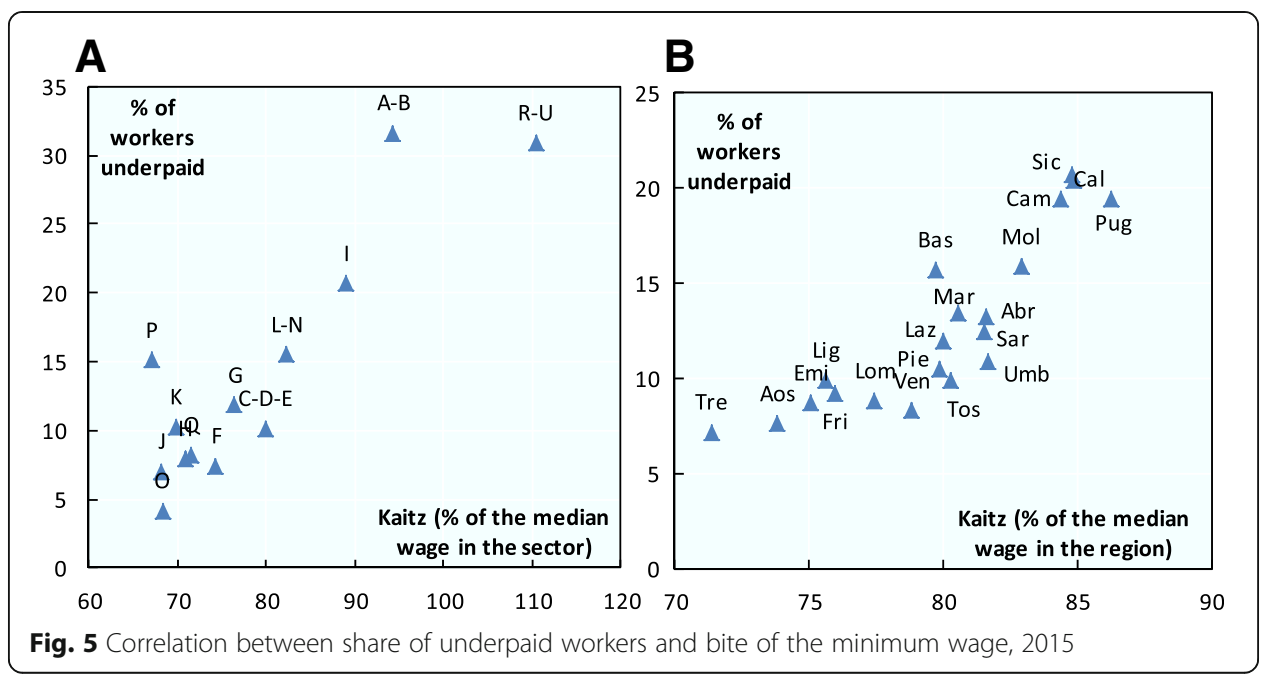

no robust correlation is found when looking at the average shortfall per underpaid worker. These results show that the sectoral wage floors fixed at a national level are broadly non-binding across region and firm size groups and there is no sign of the socalled lighthouse effect (Baltar and Souza, 1980 called "efeito farol" the phenomenon observed in some emerging economies where increases in the minimum wage for covered workers also lead to increases in the wages for uncovered workers). In Italy, when the sectoral wage floor increases, wages in the bottom of the distribution appear to be largely unaffected leading to a mechanical increase in both the share of underpaid workers and the depth of violation (as the threshold has moved up). ${ }^{14}$ Results are robust also when using INPS data (Table 12 in Appendix 2). ${ }^{15}$ In the absence of effective enforcement, minimum wage increases are, therefore, not reflected in pay increases for workers at the bottom of the distribution.

\subsection{Robustness tests}

As discussed, in the case of Italy, the Labour Force Survey is the most comprehensive data source for this kind of analysis but it may be subject to measurement and processing error. Therefore, we also test the robustness of the results using individual (gross) wages in the Structure of Earnings Survey for Italy and social security records by INPS (which on the opposite, being filled by employers are less likely to report underpayment). We consider workers to be underpaid if they are paid less than $95 \%$ of the reference minimum wage (since wages and hours are reported by employers, they are less subject to measurement error, while they may on purpose under-report hours of work to keep them in line with established rules and hourly pay rates).

Table 9 shows the results using SES and INPS. As expected, the estimates of noncompliance are lower using SES or INPS. The share of underpaid workers in SES is $30 \%$ lower than that in the LFS in 2010 but this is mostly driven by composition effects. If one excludes micro firms, agriculture and the public sector, the estimates for LFS are only slightly above those with the SES (see Table 13 in Appendix 3 for comparable LFS estimates based on the same sample as SES). Those for INPS cover only violations in annual wages and should therefore be compared to the estimates for violations in 
Garnero IZA Journal of Labor Policy (2018) 7:3

Page 16 of 24

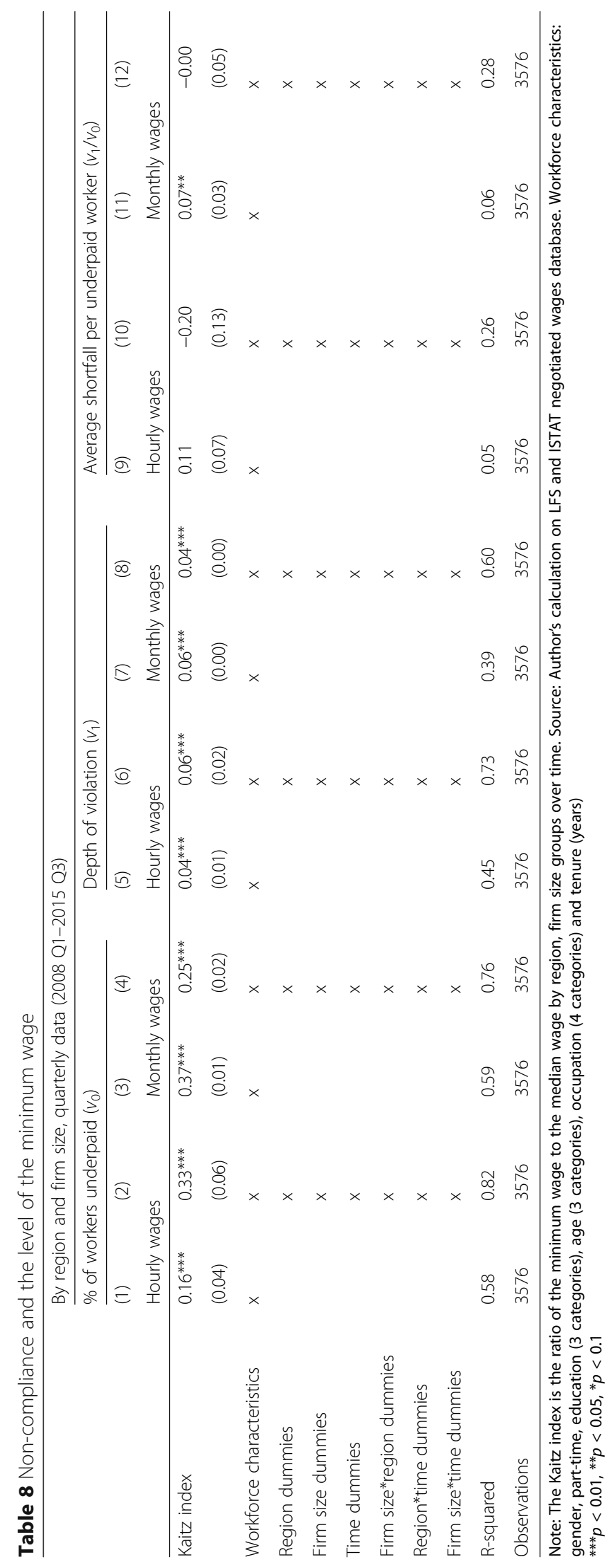


Table 9 Violation of sectoral minimum wages using SES and INPS

\begin{tabular}{|c|c|c|c|}
\hline Year & $\%$ of workers underpaid $\left(v_{0}\right)$ & Depth of violation $\left(v_{1}\right)$ & Average shortfall per underpaid worker $\left(v_{1} / v_{0}\right)$ \\
\hline \multicolumn{4}{|c|}{ SES (hourly) } \\
\hline 2010 & 7.76 & 1.43 & 18.43 \\
\hline \multicolumn{4}{|c|}{ INPS (yearly) } \\
\hline 2008 & 2.61 & 0.37 & 14.32 \\
\hline 2009 & 2.46 & 0.35 & 14.35 \\
\hline 2010 & 2.67 & 0.38 & 14.10 \\
\hline 2011 & 2.54 & 0.36 & 14.24 \\
\hline 2012 & 2.55 & 0.38 & 14.91 \\
\hline 2013 & 2.67 & 0.40 & 15.11 \\
\hline 2014 & 2.70 & 0.40 & 14.96 \\
\hline
\end{tabular}

Source: Author's calculation on ISTAT negotiated wages database, Structure of Earnings Survey and LoSai data

monthly wages shown in Fig. 2: they are considerably lower than those estimated using the LFS (in 2014, 2.7\% of workers were paid less than the monthly minimum wage using INPS compared with 7\% in LFS), even when comparing the same sample (estimates for LFS excluding the public sector are in Table 12 in Appendix 2). This discrepancy is not surprising given that administrative data are rarely a good source to measure violations to labour market regulations. Interestingly, the estimated average shortfall per underpaid worker is also lower but still comparable (17\% in SES compared with $22 \%$ in LFS using the hourly data).

The same regional, industrial and firm size patterns highlighted above can be found in SES and INPS data (Table 10). Violations are more prevalent in the South and the Islands, in hotels and restaurants and in small and medium firms. Interestingly, the share of underpaid workers in agriculture in SES and INPS data is below the national average in contrast with LFS data suggesting an important presence of undeclared underpaid work captured (at least in part) by the LFS and not in employers' and administrative surveys.

In conclusion, the results obtained using the Structure of Earnings Survey confirm those obtained using the Labour Force Survey. The estimates using administrative data from social security records (INPS) are considerably lower because employers are highly unlikely to willingly report to the social security administration wages that do not comply with sectoral minima, but still not negligible. However, the main trends across sectors, regions and workforce groups are confirmed both with SES and INPS.

\section{Conclusions}

The analysis in this paper has shown that sectoral minimum wages in Italy are relatively high both in absolute terms and relative to the median. This is well above for instance the German statutory minimum wage of 8.50 euros and close to the French one at 9.61 euros in 2015. Moreover, sectoral wage floors have continued to increase in the last decade, even during the crisis, despite flat productivity growth.

The flip, and often overlooked, side of high sectoral minimum wages in Italy is the relatively high level of non-compliance. All employees in Italy should at least be paid the minima fixed by sectoral agreements, but the analysis in this paper has shown that on average around $10 \%$ of workers are paid an average $20 \%$ less than the sectoral 
Table 10 Share of workers paid less than the minimum $\left(v_{1}\right)$ using SES and INPS, by geographical area, sector and firm size

\begin{tabular}{|c|c|c|c|}
\hline \multicolumn{4}{|l|}{ Geographical area } \\
\hline INPS (annual, 2014) & & SES (hourly, 2010) & \\
\hline North West & 1.76 & North West & 6.99 \\
\hline North East & 1.64 & North East & 7.72 \\
\hline Center & 2.59 & Center & 7.33 \\
\hline South & 6.80 & South & 9.67 \\
\hline Islands & 5.09 & Islands & 8.58 \\
\hline \multicolumn{4}{|l|}{ Sector } \\
\hline INPS (annual, 2014) & & SES (hourly, 2010) & \\
\hline A-B-C Agriculture and mining & 0.87 & - & - \\
\hline D-E Manufacturing, elec. \& water supply & 3.01 & C-D-E Manufacturing, elec. \& water supply & 6.15 \\
\hline F Construction & 1.73 & F Construction & 6.26 \\
\hline G Retail trade & 1.90 & G Retail trade & 2.73 \\
\hline H Hotel and restaurants & 4.15 & H Transport & 7.97 \\
\hline I Transports & 1.99 & I Hotels and restaurants & 8.18 \\
\hline J Fin. Intermediation & 4.39 & $\mathrm{~J}$ Information and communication & 3.25 \\
\hline K Real estate & 1.94 & K Finance and insurance & 2.92 \\
\hline \multirow[t]{4}{*}{ L-Q Education, health and others } & 3.51 & L-N Real estate, professional \& admin activities & 21.52 \\
\hline & & P Education & 6.65 \\
\hline & & Q Health & 7.91 \\
\hline & & R-U Arts, other activities, household and intl organisations & 13.18 \\
\hline \multicolumn{4}{|l|}{ Firm size } \\
\hline INPS (annual, 2014) & & SES (hourly, 2010) & \\
\hline Less than 10 employees & 6.02 & - & - \\
\hline 11-15 employees & 3.69 & $10-49$ & 9.87 \\
\hline 16-19 employees & 3.78 & & \\
\hline 20-49 employees & 2.68 & & \\
\hline 50-299 employees & 2.05 & $50-249$ & 6.60 \\
\hline 300 or more employees & 1.01 & $250+$ & 7.20 \\
\hline
\end{tabular}

minimum. Getting a precise estimate of underpaid workers is complex because of measurement and sampling errors, but results using alternative employer surveys or social security data confirm the broad trends. Non-compliance is particularly high in the South and in micro and small firms. This is a major issue for the Government and social partners (not just unions but also for employers' organisations which wish to ensure a level playing field across all firms).

These findings call for a reflection on the functioning of the Italian collective bargaining systems. Negotiated wages are high but do not appear to be binding and therefore they fail to ensure a level playing field for firms and are not reflected in pay increases for workers at the bottom of the distribution. How can the government and social partners increase compliance? This paper provides only a statistical portrait of non-compliance, but building on existing literature and international experiences, some policy levers can be identified and discussed. 
To increase compliance, a reform of the current institutional system could be envisaged. For instance, a move from rigid minima fixed for all firms and workers in the same sector to wage floors that better take into account local and firm specificities and economic conditions could contribute to increase compliance (but would also reduce the gains to workers in compliant firms). Such a shift however may increase the complexity of the system which may lead to opposite results. Moreover, a higher presence of unions at the establishment level would also help in this respect by ensuring a more direct control on the workplace (however, many firms, especially the micro and small ones, would most probably still be left out).

Without touching current institutional settings, which is complicated and often controversial, some practical and relatively cost-free actions could be taken by labour inspection authorities and social partners (Benassi, 2011 provides a comprehensive review of the main approaches adopted across the world to improve compliance to minimum wages). Effective labour inspections on site but also using available data and technology and sanctions are the most important tools to increase compliance. However, alternative, more original and relatively cost-limited strategies can also be pursued (even independently from the Government by social partners themselves). For instance, the complexity of the system may be an important cause of non-compliance as found by Rani et al. (2013) in developing countries. A smaller number of collective agreements and wage floors could make the Italian system more readable for both employers and workers. In addition, ensuring that agreements are signed by representative unions and employers' organisations would allow fighting against "pirate agreements" signed with complacent poorly representative or "yellow" trade unions which undermine existing wage floors. Moreover, making the information on negotiated wages publicly and easily available (currently it is not at all the case) would help employers who are underpaying by mistake but also workers who may not push for the correct salary as they lack info about their level. Furthermore, a hotline and/or an online form could be established to provide free and confidential advice to employers, employees and their representatives on wages and more general on employment rights and workplace conflict (experiences in the $\mathrm{UK}^{16}$ and Germany ${ }^{17}$ provide useful examples). Once these tools are available, an awareness campaign across the country could be launched to discuss the importance of compliance and present the tools available to employers and workers (the $\mathrm{UK}^{18}$ and Costa Rica, see Gindling et al. 2014, provide useful examples). Finally, "naming and shaming" campaigns have been used in some developing countries (Indonesia and Brazil) but also in the $\mathrm{UK}^{19}$ to publicly disclose the names of firms not complying with the minimum wage regulation. ${ }^{20}$

In conclusion, fighting non-compliance in Italy is essential to restore a level playing field for firms and ensure effective pay increases for all workers and a series of relatively lowcost tools could be immediately mobilised by inspection authorities and social partners.

\section{Endnotes}

${ }^{1}$ Basu et al. (2010) showed that, when competition, enforcement and commitment are not perfect, turning a blind eye can be an efficient, and credible, strategy for governments more interested in efficiency than in distribution.

${ }^{2}$ This is formally against Article 2 of the ILO Convention 98 on the Right to Organise and Collective Bargaining. However, in the absence of clear and stringent rules on the representativeness of social partners and without a national minimum wage, "pirate 
agreements" with yellow unions are legal as far as they respect the procedural requirements of the law (see Tomassetti, 2016 for the case of Italy).

${ }^{3}$ Much of that recorded non-compliance appears to have been related to apprenticeships. Since 2013, when apprentices could be identified in the data, non-compliance among youth has fallen significantly.

${ }^{4} \mathrm{~A}$ series of agreements among the social partners as well as the national regulation have progressively widened the scope for opting-out clause (D'Amuri and Giorgiantonio, 2015). However, there remains a strong tension between the rules set by social partners autonomously, which define a strict hierarchy between bargaining levels, and jurisprudence, according to which a firm-level agreement can always depart from sector-level agreements (OECD, 2017). The Italian collective bargaining system remains largely centralised, at least compared to those in Germany or the Nordic countries where firm-level bargaining plays a much more significant role.

${ }^{5} \mathrm{An}$ alternative source on minimum wages by sector is represented by the database collected by WageIndicator.org, but their coverage is less systematic than the one by ISTAT, negotiated hours of work are not indicated (and hence we would be able to consider full-time workers) and the mapping between branches and NACE code is not straightforward in the absence of a mapping as for ISTAT.

${ }^{6}$ The differences in the estimated Kaitz indices using the LFS, SES or INPS may be driven by different sectoral composition (the LFS covers the entire economy, while SES excludes agriculture and public sector and small firms and INPS excludes the public sector) but also to reporting errors or biases (LFS wage data are self-reported by workers while SES and INPS are reported by employers). More on this in Section 3.1.

${ }^{7}$ See Section 3.1 for details on how the two sources have been merged.

${ }^{8}$ Previous studies have found that measurement error in wage and earnings data as reported in surveys is non-classical and mean reverting (Gottschalk and Huynh, 2010): wage (or incomes) at the bottom are overestimated while wages at the top are underestimated. To the extent that this is valid also for wages in the Italian Labour Force Survey this should underestimate the share of underpaid workers rather than overestimate it.

${ }^{9}$ Another source of error could come from the bottom coding of wages in the LFS (top coding is not relevant for underpayment). Bottom coding at 250 euros/month is well below the negotiated minima, and therefore, it does not affect the estimation of the headcount of underpaid workers. However, it could lead to a partial underestimation of the depth of violation.

${ }^{10}$ Individuals are selected on the basis of their date of birth (all persons born the 1st or 9th of each month).

${ }^{11}$ Or they report formally compliant wages just for pension and social security purposes while in fact workers are paid only "envelope wages" (in Italian salari fuoribusta) to avoid tax liabilities.

${ }^{12} \mathrm{~A}$ comparison of the distribution of wages in the three datasets shown in Figure 6 in Appendix 4.

${ }^{13}$ Another source of potential underpayment comes from the increasing fragmentation of employers' organisations. In the recent years, there has been a series of divisions in employers' organisations (firms setting up alternative employers' organisations to be freed from the agreement's obligations, beyond the famous FIAT case). In the cases of the retail trade and the tourism sector, for instance, these divisions have allowed the exiting 
organisations to continue applying the previous agreement (with lower wages) waiting for a renewal that has not been signed yet.

${ }^{14}$ The wage distributions in LFS, SES and INPS also show no spike around the sectoral wage floors (Figure 7 in Appendix 5).

${ }^{15}$ If anything, they not only show that when the minimum wage relative to the median increases, the share of underpaid and the depth of violation increase, but also that the average shortfall per underpaid worker increases as if minimum wage increases for covered workers were compensated by lower wages for uncovered workers. A further test using SES data cannot be run as only a cross section for 2010 is available.

${ }^{16}$ In the UK the helpline received around 1000 calls per week in 2006/2007 and 670 in 2008/2009 but only around 50 per week concerning complaints of underpayment (HMRC data reported in Benassi, 2011). See https://www.gov.uk/pay-and-work-rights and http://www.acas.org.uk/index.aspx?articleid=2042

${ }^{17}$ In Germany, calls to the helpline were around 4000 per week in the very first weeks of the application of the new minimum wage in January 2015 and then stabilised around 500 calls per week since mid-2015 (Mindestlohn Kommission, 2016). See http://www.der-mindestlohn-wirkt.de/ml/DE/Ihre-Fragen/Mindestlohn-Hotline/artikel-mindestlohn-hotline.html

${ }^{18}$ Benassi (2011) reported that between October 2007 and March 2008, the UK Government undertook five campaigns, making use of different communication methods such as radio advertising, posters, leaflets, a publicity bus and the internet and they led to an increase in calls to the UK HMRC helpline by $400 \%$, and in the knowledge of the minimum wage rates for different age groups from 10 to $70 \%$ according to the UK Low Pay Commission.

${ }^{19}$ The most recent list of firms who have failed to pay their workers the national minimum wage in the UK can be found here https:/www.gov.uk/government/news/ record-number-of-employers-named-and-shamed-for-underpaying.

${ }^{20}$ Firms not complying with the minimum wage could also be expelled from the employers' organisation (as one of the employers' organisation Confindustria did in the case of firms paying the "pizzo", protection money, to the Mafia) and suspended from public tenders and funds.

\section{Appendix 1}

Table 11 Hourly sectoral minimum wages (euros per hour and Kaitz index) using alternative datasets

\begin{tabular}{|c|c|c|c|c|c|}
\hline Year & $\begin{array}{l}\text { Minimum wages } \\
\text { (average across sectors) }\end{array}$ & $\begin{array}{l}\text { Kaitz } \\
\text { (\% of the median) }\end{array}$ & $\begin{array}{l}\text { Minimum of } \\
\text { the minima }\end{array}$ & $\begin{array}{l}\text { Maximum of } \\
\text { the minima }\end{array}$ & Median \\
\hline \multicolumn{6}{|c|}{ SES (hourly) } \\
\hline 2010 & 8.83 & 66.86 & 6.99 & 12.43 & 13.21 \\
\hline \multicolumn{6}{|c|}{ INPS (annual) } \\
\hline 2008 & $15,618.48$ & 63.49 & $12,644.77$ & $23,660.97$ & 24,600 \\
\hline 2009 & $16,044.67$ & 63.67 & $13,219.31$ & $23,968.28$ & 25,200 \\
\hline 2010 & $16,671.46$ & 64.62 & $13,155.34$ & $23,917.00$ & 25,800 \\
\hline 2011 & $16,999.96$ & 63.91 & $13,334.37$ & $24,083.63$ & 26,600 \\
\hline 2012 & $17,316.25$ & 63.66 & $13,636.62$ & $24,593.61$ & 27,200 \\
\hline 2013 & $17,629.66$ & 63.88 & $13,803.80$ & $25,141.04$ & 27,600 \\
\hline 2014 & $17,873.13$ & 64.06 & $13,923.72$ & $25,853.12$ & 27,900 \\
\hline
\end{tabular}

Note: The average hourly minimum and the minimum of the minima differ between LFS and SES in 2010 because SES does not cover agriculture and the public sector. Source: Author's calculation on ISTAT negotiated wages database and the Structure of Earnings Survey and LoSai INPS social security data 


\section{Appendix 2}

Table 12 Minimum wage violations and the Kaitz index (minimum/median wage) using INPS data

\begin{tabular}{|c|c|c|c|c|c|c|}
\hline & \multicolumn{2}{|c|}{$\%$ of workers underpaid $\left(v_{0}\right)$} & \multicolumn{2}{|c|}{ Depth of violation $\left(v_{1}\right)$} & \multicolumn{2}{|c|}{$\begin{array}{l}\text { Average shortfall per } \\
\text { underpaid worker }\left(v_{1} / v_{0}\right)\end{array}$} \\
\hline & (1) & (2) & (3) & (4) & (5) & (6) \\
\hline \multirow[t]{2}{*}{ Kaitz index } & $0.41^{* * *}$ & $0.41^{* * *}$ & $0.09^{* * *}$ & $0.07^{* * *}$ & $0.10^{* * *}$ & $0.12^{* * *}$ \\
\hline & $(0.01)$ & $(0.01)$ & $(0.00)$ & $(0.00)$ & $(0.01)$ & $(0.03)$ \\
\hline Workforce characteristics & $x$ & $x$ & $x$ & $x$ & $x$ & $x$ \\
\hline Region dummies & & $x$ & & $x$ & & $x$ \\
\hline Firm size dummies & & $x$ & & $x$ & & $x$ \\
\hline Time dummies & & $x$ & & $x$ & & $x$ \\
\hline Firm size*region dummies & & $x$ & & $x$ & & $x$ \\
\hline Region*time dummies & & $x$ & & $x$ & & $x$ \\
\hline Firm size*time dummies & & $x$ & & $x$ & & $x$ \\
\hline R-squared & 0.39 & 0.82 & 0.37 & 0.76 & 0.03 & 0.52 \\
\hline Observations & 7234 & 7234 & 7234 & 7234 & 7234 & 7234 \\
\hline
\end{tabular}

Source: Author's calculation on INPS and ISTAT negotiated wages database. Workforce characteristics: gender, age (3 categories) and occupation (4 categories)

${ }^{* * *} p<0.01,{ }^{* *} p<0.05,{ }^{*} p<0.1$

\section{Appendix 3}

Table 13 Share of underpaid workers $\left(v_{1}\right)$ in LFS using samples comparable to SES and INPS

\begin{tabular}{lll}
\hline Year & $\begin{array}{l}\text { Excluding micro firms, agriculture } \\
\text { and public sector (comparable with SES) } \\
\text { Hourly wage }\end{array}$ & $\begin{array}{l}\text { Excluding public sector } \\
\text { (comparable with INPS) }\end{array}$ \\
\hline 2008 & 7.24 & Monthly wages \\
\hline 2009 & 7.50 & 6.06 \\
2010 & 7.91 & 6.40 \\
2011 & 8.75 & 6.84 \\
2012 & 7.27 & 7.47 \\
2013 & 7.87 & 6.13 \\
2014 & 8.99 & 6.69 \\
\hline
\end{tabular}

Source: Author's calculation on ISTAT negotiated wages database and the Structure of Earnings Survey and LoSai INPS social security data

\section{Appendix 4}

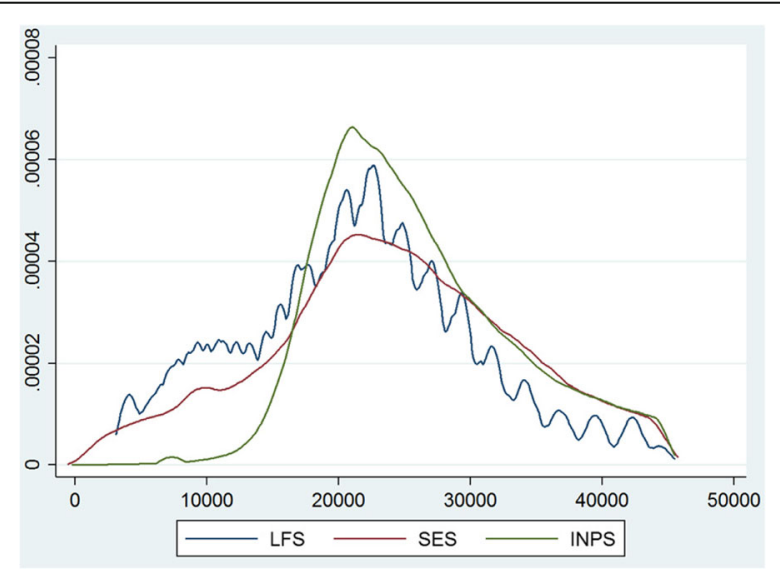

Fig. 6 Distribution of monthly wages in LFS, SES and INPS, 2010 


\section{Appendix 5}

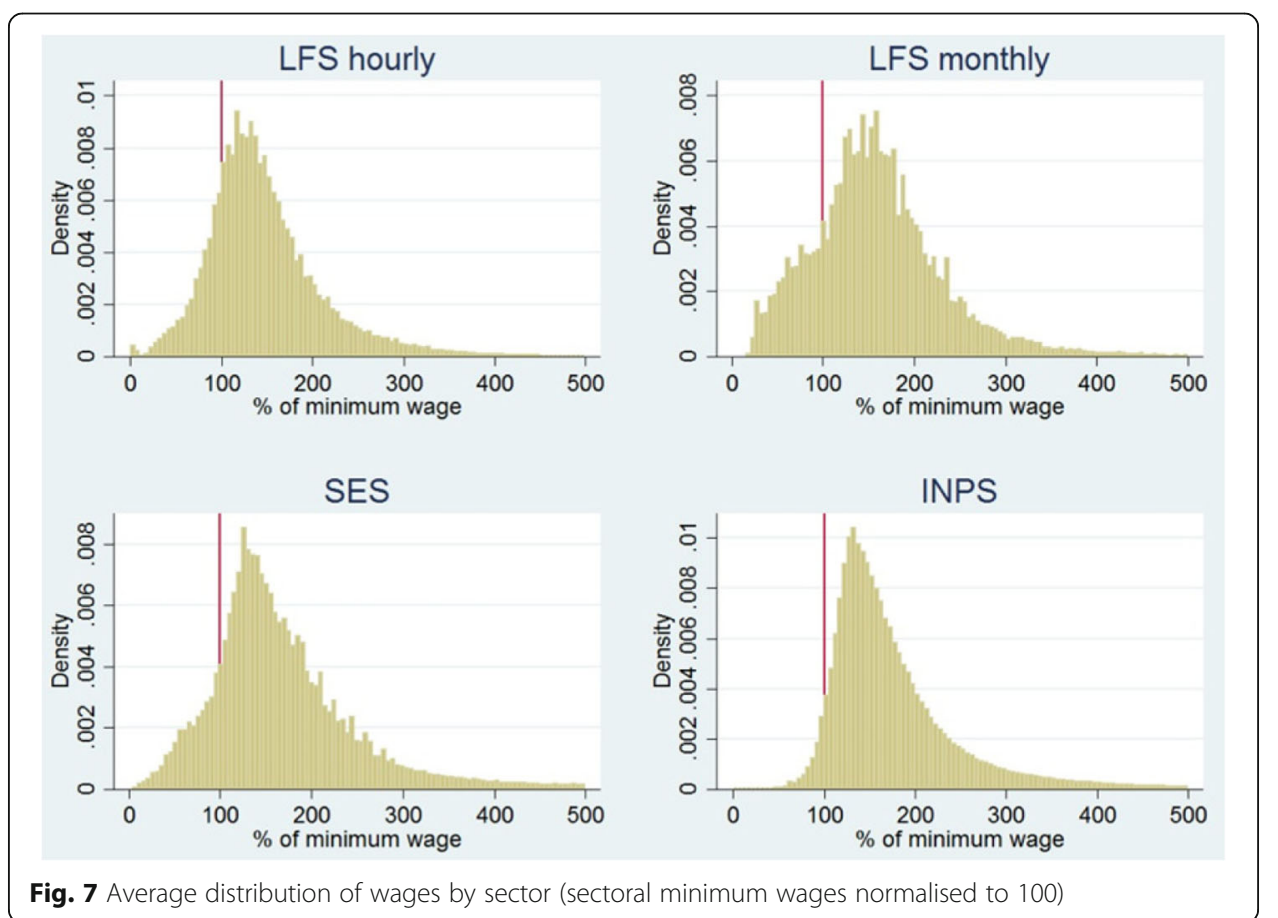

\section{Acknowledgements}

The author is grateful to the editor and an anonymous referee as well as to Andrea Bassanini, Chiara Benassi, Tim Butcher, Tim Gindling, Alexander Hijzen, Stephan Kampelmann, Marco Leonardi, Piotr Lewandowski, Thomas Manfredi, Emiliano Rustichelli, Shruti Singh, Paolo Tomassetti and seminars participants at the OECD and the University of Bergamo and Adapt for helpful comments and discussions. Livia Fioroni, Pierluigi Minicucci and Sébastien Martin provided invaluable help with the data. The views expressed in this paper are those of the author and cannot be attributed to the OECD or its member countries. The author is solely responsible for any remaining errors. Responsible editor: Juan Jimeno.

\section{Competing interests}

The IZA Journal of Labor Policy is committed to the IZA Guiding Principles of Research Integrity. The author declares that he has observed these principles.

\section{Publisher's Note}

Springer Nature remains neutral with regard to jurisdictional claims in published maps and institutional affiliations.

\section{Author details}

${ }^{1} \mathrm{OECD}, 2$, rue André Pascal -, 75775 Paris Cedex 16, France. ${ }^{2} \mathrm{CEB}$, Université libre de Bruxelles, Brussels, Belgium. ${ }^{3} \mathrm{IZA}$, Bonn, Germany.

Received: 22 December 2017 Accepted: 29 January 2018

Published online: 21 February 2018

\section{References}

Allegretto, S. and M. Reich (2015), "Are local minimum wages absorbed by price increases? Estimates from internet-based restaurant menus", IRLE working paper 124-15

Ashenfelter O, Smith R (1979) Compliance with the minimum wage law. J Polit Econ 87(2):333-350

Baltar P, Souza P (1980) Salário mínimo e taxa de salários no Brasil-Réplica. Pesquisa e Planejamento Econômico 10(3)

Bartelsman E, Doms M (2000) Understanding productivity: lessons from longitudinal microdata. J Econ Lit 38(3):569-594

Basu K, Chau N, Kambur R (2010) Turning a blind eye: costly enforcement, credible commitment and minimum wage laws. Econ J 120(543):244-269

Benassi C (2011) The implementation of minimum wage: challenges and creative solutions, Working paper no. 12. International Labour Office and Global Labour University. ILO Working Paper, Geneva. http://www.global-labouruniversity.org/fileadmin/GLU_Working_Papers/GLU_WP_No.12.pdf

Bhorat H, Kanbur R, Mayet N (2012) Minimum wage violation in South Africa. Int Labor Rev 151(3):277-287

Bhorat H, Kanbur R, Mayet N (2013) A note on measuring the depth of minimum wage violation. Labour 27(2):192-197 
Bhorat H, Kanbur R, Stanwix B (2015) Minimum wages in sub-Saharan Africa: a primer, Working papers 201503. University of Cape Town, Development Policy Research Unit. IZA Discussion papers, IZA Bonn. http://ftp.iza.org/ dp9204.pdf

Card D, Krueger A (1994) Minimum wages and employment: a case study of the FastFood industry in New Jersey and Pennsylvania. Am Econ Rev 84(5):772-793

Comola M, De Mello L (2011) How does decentralized minimum wage setting affect employment and informality? The case of Indonesia. The Review of Income and Wealth 57(s1):S79-S99

D'Amuri F, Giorgiantonio C (2015) The institutional and economic limits to bargaining decentralization in Italy, IZA policy papers 98. Institute for the Study of Labor (IZA). IZA Discussion papers, IZA Bonn. http://ftp.iza.org/pp98.pdf

Draca M, Machin S, Van Reenen J (2011) Minimum wages and firm profitability. Am Econ J Appl Econ 3(1):129-151

Garnero A, Kampelmann S, Rycx F (2015) Sharp teeth or empty mouths? European institutional diversity and the sector-level minimum wage bite. Br J Ind Relat 53(4):760-788

Gindling T, Terrell K (2005) Legal minimum wages and the wages of formal and informal sector workers in Costa Rica. World Dev 33(11):1905-1921

Gindling, T. H., N. Mossaad and J. Trejos (2014), "The consequences of increased enforcement of legal minimum wages in a developing country: an evaluation of the impact of the Campana Nacional de Salarios Mínimos in Costa Rica", IZA discussion papers 8253

Giugni G (1957) Bargaining units and labor Organization in Italy. Ind Labor Relat Rev 10(3):424-439

Goraus, K. and P. Lewandowski (2016), Minimum wage violation in central and Eastern Europe, IZA discussion papers 1009

Gottschalk P, Huynh M (2010) Are earnings inequality and mobility overstated? The impact of non-classical measurement error. Rev Econ Stat 92:302-315

Kamińska, A. and P. Lewandowski (2015), "The effects of minimum wage on a labour market with high temporary employment", IBS working papers 07/2015, Institute for Structural Research (IBS). IBS Working Paper, IBS Warsaw. http://ibs.org.pl/app/uploads/2015/02/IBS_Working_Paper_07_2015.pdf

Kanbur R, Ronconi L, Wedenoja L (2013) Labour law violations in Chile. Int Labour Rev 152(3-4):431-444

Lucifora C (2017) "Il salario minimo: contrattazione o minimo legale?" in Dell'Aringa, Lucifora, Treu (eds.) "Salari, produttività, diseguaglianze", AREL, II Mulino

MaCurdy T (2015) How effective is the minimum wage at supporting the poor? J Polit Econ 123(2):497-545

Mindestlohn Kommission (2016) Erster Bericht zu den Auswirkungen des gesetzlichen Mindestlohns. Mindestlohn Kommission, Berlin. https://www.mindestlohn-kommission.de/DE/Bericht/pdf/Bericht2016.pdf?_blob=publicationFile\&v=4

Neumark D, Wascher W (1992) Employment effects of minimum and subminimum wages: panel data on state minimum wage laws. Ind Labor Relat Rev 46(1):55-81

OECD (2017) Collective bargaining in a changing world of work. In: OECD employment outlook 2017. OECD Publishing, Paris

Rani U, Belser P, Oelz M, Ranjbar S (2013) Minimum wage coverage and compliance in developing countries. Int Labour Rev 152(3-4):381-410

Riley R, Rosazza-Bondibene C (2015) Raising the standard: minimum wages and firm productivity, NIESR discussion papers 449. National Institute of Economic and Social Research, London. https://www.niesr.ac.uk/sites/default/files/ publications/Minimum\%20wages\%20and\%20firm\%20productivity\%20NIESR\%20DP\%20449.pdf

Ritchie F, Veliziotis M, Drew H, Whittard D (2016) Measuring compliance with minimum wages, Working papers in economics no. 1608. University of the West of England, Bristol, Bristol

Ronconi L (2010) Enforcement and compliance with labor regulations. Ind Labor Relat Rev 64(4):719-736

Sabia J, Burkhauser R (2010) Minimum wages and poverty: will a $\$ 9.50$ federal minimum wage really help the working poor? South Econ J 76(3):592-623

Tomassetti P (2016) La nozione di sindacato comparativamente più rappresentativo nel decreto legislativo n. 81/2015. Diritto delle Relazioni Industriali 26(2):368-392

Ye L, Gindling T, Li S (2015) Compliance with legal minimum wages and overtime pay regulations in China. IZA J Labor Dev 4(1):1-35

\section{Submit your manuscript to a SpringerOpen ${ }^{\circ}$ journal and benefit from:}

- Convenient online submission

- Rigorous peer review

- Open access: articles freely available online

- High visibility within the field

- Retaining the copyright to your article

Submit your next manuscript at $\gg$ springeropen.com 